\title{
FAKTOR-FAKTOR YANG BERHUBUNGAN DENGAN KEJADIAN HIPERTENSI PADA WANITA USIA SUBUR DI PUSKESMAS UMBULHARJO I YOGYAKARTA TAHUN 2009
}

\author{
Yufita Yeni, Sitti Nur Djannah, Solikhah \\ Fakultas Kesehatan Masyarakat Universitas Ahmad Dahlan
}

\begin{abstract}
Background: Hypertension or high blood pressure is heart and blood vessel disorder marked by increasing of blood pressure. Consequence from this incident is occurrence of other accompanying illness. Hypertension may occur in people without age and sex limitation until it needs good handling. High prevalence of childbearing age woman suffer from hypertension in Puskesmas Umbulharjo I (Public Health Service) has drove writer to make study about factors related with hypertension incident in childbearing age woman in Puskesmas Umbulharjo I Yogyakarta. Objective of this research is to recognize correlation between history of hypertension family, obesity, and hormonal contraception usage, and hypertension incident of childbearing age woman in Puskesmas Umbulharjo I Yogyakarta.

Method: This was observational analytic research using cross sectional approach. Population of this study is age group which medicinize in common polyclinic of Puskesmas Umbulharjo I Yogyakarta. Sample was taken using Accidental Sampling method. Sample comprised of childbearing age woman who suffering hypertension (having problem) and those who have not hypertension problem (having not problem), and meet respondent inclusion criterion, that resulted of 88 women.

Result: Result of this study showed there is no correlation between history of hypertension family with hypertension incident, that is $p=0,158,>\alpha=0,05$, calculated chi square is $1.992<$ tabulated chi square of 3,481. There is correlation between obesity and hypertension incident with $p$ value of 0,007 $<\alpha=0,05$, and calculated chi square is $7,298>$ tabulated Chi Square of 3,481. There is no correlation between hormonal contraception and hypertension incident with value of $p=0,762>\alpha=0.05$, and calculated Chi Square of $0.091<$ tabulated Chi Square of 3,481.

Conclusion: There was no correlation between history of hypertension family and hormonal contraception with hypertension incident. There is correlation between obesity and hypertension incident.
\end{abstract}

Keywords: hypertension, history of hypertension family, obesity, hormonal contraception.

\section{PENDAHULUAN}

Penyakit kardiovaskuler merupakan problema kesehatan utama dinegara maju dan berkembang, sehingga menjadi penyebab kematian nomor satu di dunia begitu juga di Indonesia, baik untuk laki-laki maupun untuk perempuan. Data dari WHO, pada tahun 2005, sekitar 17,5 juta orang meninggal karena penyakit kardiovaskuler atau 30 persen dari kematian diseluruh dunia. ${ }^{1}$

Salah satu penyakit kardiovaskuler tersebut adalah Hipertensi, hipertensi atau yang lebih dikenal dengan penyakit darah tinggi adalah suatu keadaan dimana seseorang mengalami peningkatan tekanan darah diatas normal. Hasil Riskesdas 2007 menyebutkan, bahwa stroke, hipertensi dan penyakit jantung meliputi lebih dari sepertiga penyebab kematian, dimana stroke menjadi penyebab kematian terbanyak 15,4 persen, kedua hipertensi 6,8 persen, penyakit jantung iskemik 5,1 persen, dan penyakit jantung 4,6 persen. $^{2}$ 
Pengukuran tekanan darah menggunakan sphygmomanometer dan stetoskop, akan menghasilkan dua buah angka hasil pencatatan, yaitu tekanan darah sistole dan tekanan darah diastole. Angka pertama yang lebih besar nilainya, menunjukkan tekanan darah sistole, dan angka kedua yang lebih kecil nilainya, menunjukkan tekanan darah diastoel. Sistole adalah tekanan darah pada saat jantung memompa darah ke dalam pembuluh nadi (saat jantung mengkerut). Diastole adalah tekanan darah pada saat jantung mengembang dan menyedot darah kembali atau pembuluh nadi mengempis kosong. ${ }^{2}$

Data Riskesdas 2007 juga disebutkan prevalensi hipertensi di Indonesia berkisar 30 persen dengan insiden komplikasi penyakit kardiovaskular lebih banyak pada perempuan sekitar 52 persen dibandingkan laki-laki yaitu sebanyak 48 persen. ${ }^{2}$ Umumnya penderita hipertensi adalah orang yang berusia diatas 40 tahun, namun pada saat ini tidak menutup kemungkinan diderita oleh orang usia muda. Hipertensi pada wanita usia subur sebagian besar terjadi pada usia 25 - 45 tahun, dan hanya pada 20 persen terjadi dibawah usia 20 tahun. $^{3}$

Terdapat adanya kecenderungan bahwa masyarakat perkotaan lebih banyak menderita hipertensi dibandingkan masyarakat pedesaan, ini dihubungkan dengan adanya gaya hidup masyarakat kota yang selalu menginginkan kehidupan yang serba instant. Perbandingan antara perempuan dan pria bila ditinjau, ternyata hipertensi yang disebabkan oleh pengaruh gaya hidup ini juga lebih banyak terjadi pada wanita, khususnya wanita usia subur ${ }^{4}$. Wanita usia subur merupakan wanita yang berusia $15-45$ tahun, pada masa ini sering terjadi perubahan hormonal didalam tubuh yang disebabkan karena pola hidup yang salah ${ }^{5}$. Hipertensi masih tetap menjadi masalah karena beberapa hal, antara lain masih banyaknya pasien hipertensi yang belum mendapat pengobatan maupun yang sudah diobati tetapi tekanan darahnya belum mencapai target, serta adanya penyakit penyerta atau komplikasi yang dapat meningkatkan morbiditas dan mortalitas. ${ }^{1}$

Terdapat 478 kasus pada usia subur, yaitu pada usia 15-45 tahun, untuk hipertensi pada wanita usia subur berjumlah 466 orang. Jumlah tersebut tergolong tinggi, hal ini disebabkan karena wanita pada usia subur kurang memperhatikan kesehatan, misalnya gaya hidup yang tidak sehat seperti penggunaan obat - obatan hormonal atau konsumsi makanan - makanan cepat saji. Terlihat bahwa dengan bertambahnya usia maka kemungkinan untuk terjadinya hipertensi akan semakin tinggi. Laki - laki lebih banyak menderita hipertensi pada usia 40 tahun keatas. ${ }^{6}$

Hipertensi merupakan penyakit yang dapat dicegah dengan mengendalikan faktor risiko yang sebagian besar merupakan faktor prilaku dan kebiasaan hidup. Apabila seseorang mau menerapkan gaya hidup sehat, maka kemungkinan besar akan terhindar dari hipertensi. Penyakit ini berjalan terus seumur hidup dan sering tanpa adanya keluhan yang khas selama belum terjadi komplikasi pada organ tubuh. Faktor risiko hipertensi antara lain adalah faktor genetik, umur, jenis kelamin, etnis, stress, obesitas, asupan garam, penggunaan obat hormonal, dan kebiasaan merokok. ${ }^{1}$ Berdasarkan latar belakang diatas, penelitian ini bertujuan untuk mencari Faktor-Faktor yang Berhubungan dengan Kejadian Hipertensi pada Wanita Usia Subur di Puskesmas Umbulharjo I Yogyakarta Tahun 2009. 


\section{METODE PENELITIAN}

Penelitian ini merupakan penelitian analitik observasional dengan menggunakan rancangan cross sectional. Populasi dalam penelitian ini adalah wanita semua kelompok umur yang berobat di Poliklinik Umum Puskesmas Umbulharjo I Yogyakarta.

Analisis Univariat dengan menyajikan distribusi frekuensi dari variabel-variabel yang diteliti. Analisis ini digunakan untuk memperoleh gambaran pada masing-masing variabel yang diteliti dan disajikan dengan menggunakan tabel distribusi frekuensi.

Analisis Bivariate yaitu menganalisis dua varibel yang diduga mempunyai hubungan atau berkolerasi. Analisis kedua variabel tersebut menggunakan uji statistik $\mathrm{X}^{2}$ (chi square), apabilah nilai $\mathrm{X}^{2}$ (chi square) hitung $>\mathrm{X}^{2}$ (chi square) tabel maka artinya ada hubungan yang bermakna antara variabel bebas dengan variabel terikat.

\section{HASIL PENELITIAN DAN PEMBAHASAN}

\section{a. Hasil Penelitian}

1) Usia

Tabel 1. Distribusi Responden Berdasarkan Umur di Puskesmas Umbulharjo I Yogyakarta Tahun 2009

\begin{tabular}{clc}
\hline No & Umur & Frekuensi \\
\hline 1 & 15-24 Tahun & 3 \\
\hline 2 & $25-34$ Tahun & 41 \\
\hline 3 & 35-45 Tahun & 44 \\
\hline & Total & 88 \\
\hline
\end{tabular}

Berdasarkan tabel diatas dapat dilihat bahwa range umur responden adalah 34.5 tahun, dengan umur tertinggi 45 tahun dan umur terendah 20 tahun.

2) Pekerjaan

Tabel 2. Distribusi Responden Berdasarkan Pekerjaan di Puskesmas Umbulharjo I Yogyakarta Tahun 2009

\begin{tabular}{clcc}
\hline No & Pekerjaan & Frekuensi & Persentase (\%) \\
\hline 1 & Wiraswasta & 85 & 96.6 \\
\hline 2 & PNS & 3 & 3.4 \\
\hline \multicolumn{2}{r}{ Total } & 88 & 100 \\
\hline
\end{tabular}

Berdasarkan tabel diatas dapat dilihat bahwa responden rata - rata adalah seorang wiraswasta, yaitu sebanyak 85 orang. Wiraswasta disini mencakup ibu rumah tangga dan pekerja tidak tetap, seperti buruh. 
3) Distribusi responden berdasarkan status hipertensi

Tabel 3. Distribusi Responden Berdasarkan Status Hipertensi Responden di Puskesmas Umbulharjo I Yogyakarta Tahun 2009

\begin{tabular}{clcc}
\hline No & Status hipertensi & Frekuensi & Persentase (\%) \\
\hline 1 & Hipertensi & 26 & 29.5 \\
\hline 2 & Tidak hipertensi & 62 & 70.5 \\
\hline & Total & 88 & 100
\end{tabular}

Berdasarkan tabel 3 diatas, menjelaskan bahwa dari 88 responden yang diteliti, sebanyak 26 responden (29.5\%) menderita hipertensi, sedangkan yang tidak menderita hipertensi sebanyak 62 responden $(70.5 \%)$.

4) Distribusi responden berdasarkan riwayat keluarga

Tabel 4. Distribusi Responden Berdasarkan Riwayat Keluarga Hipertensi di Puskesmas Umbulharjo I Yogyakarta Tahun 2009

\begin{tabular}{|c|c|c|c|}
\hline No & Riwayat Keluarga & Frekuensi & Persentase (\%) \\
\hline 1 & Ada & 58 & 65.9 \\
\hline 2 & Tidak ada & 30 & 34.1 \\
\hline & Total & 88 & 100 \\
\hline
\end{tabular}

Berdasarkan tabel 4 menunjukkan bahwa dari 88 responden, sebanyak 58 responden (65.9) memiliki riwayat keluarga yang menderita hipertensi.

5) Distribusi responden berdasarkan status obesitas

Tabel 5. Distribusi Responden Berdasarkan Tingkat Obesitas di Puskesmas Umbulharjo I Yogyakarta Tahun 2009.

\begin{tabular}{clcc}
\hline No & Status Obesitas & Frekuensi & Persentase (\%) \\
\hline 1 & Obesitas & 35 & 39.8 \\
\hline 2 & Tidak obesitas & 53 & 60.2 \\
\hline & Total & 88 & 100
\end{tabular}

Berdasarkan tabel 5 menunjukkan bahwa responden dalam penelitian ini kebanyakan tidak mengalami obesitas, yaitu sebanyak 53 responden $(60.2 \%)$.

6) Distribusi variabel kontrasepsi hormonal

Tabel 6. Distribusi Penggunaan Kontrasepsi Hormonal Pada Responden di Puskesmas Umbulharjo I Yogyakarta Tahun 2009.

\begin{tabular}{clcc}
\hline No & Kontrasepsi hormonal & Frekuensi & Persentase (\%) \\
\hline 1 & Menggunakan & 52 & 59.1 \\
\hline 2 & Tidak menggunakan & 36 & 40.9 \\
\hline & Total & 88 & 100 \\
\hline
\end{tabular}

KES MAS Vol. 4.No. 2, JUNI $2010: 76$ - 143 
Berdasarkan tabel 6 menunjukkan bahwa responden yang menggunakan kontrasepsi hormonal sebanyak 52 orang (59.1\%), dan responden yang tidak menggunakan kontrasepsi hormonal sebanyak 36 orang (40.9\%). Responden yang menggunakan kontrasepsi hormonal rata - rata memakai alat kontrasepsi hormonal jenis Suntik. Alasan kenapa masyarakat memilih suntik karena disamping harganya terjangkau, pemakaiannya juga lebih mudah dan tingkat keefektifannya cukup tinggi.

7) Hubungan antara riwayat keluarga dengan kejadian hipertensi

Tabel 7. Hubungan Riwayat Keluarga Penderita Hipertensi dengan Kejadian Hipertensi di Puskesmas Umbulharjo I Yogyakarta Tahun 2009

\begin{tabular}{|c|c|c|c|c|c|c|c|}
\hline \multirow[t]{2}{*}{$\begin{array}{l}\text { Riwayat } \\
\text { hipertensi }\end{array}$} & \multicolumn{2}{|c|}{$\begin{array}{l}\text { Kejadian } \\
\text { hipertensi }\end{array}$} & \multirow{2}{*}{ Total } & \multirow{2}{*}{$p$} & \multirow{2}{*}{$\alpha$} & \multirow{2}{*}{$\begin{array}{c}\text { Chi-square } \\
\text { hitung }\end{array}$} & \multirow[t]{2}{*}{ df } \\
\hline & $\mathrm{Ya}$ & Tidak & & & & & \\
\hline Positif & 20 & 38 & 58 & & & & \\
\hline Negatif & 6 & 24 & 30 & 0,158 & 0.05 & 1.992 & $1=3.481$ \\
\hline Total & 26 & 62 & 88 & & & & \\
\hline
\end{tabular}

Tabel 7 dilihat bahwa terdapat 20 responden yang positif hipertensi dan memiliki riwayat keluarga hipertensi, responden yang tidak mengalami hipertensi tetapi memiliki riwayat keluarga yang menderita hipertensi adalah sebanyak 38 responden, responden yang mengalami hipertensi tetapi tidak memiliki riwayat keluarga yang menderita hipertensi 6 responden, responden yang tidak mengalami hipertensi dan tidak memiliki riwayat keluarga yang menderita hipertensi adalah 24 responden. Berdasarkan hasil pengolahan data menunjukkan bahwa nilai $p=0.158>\alpha=0.05$, dan Chi Square hitung $1.992<$ Chi Square tabel 3,481 , berarti secara statistik tidak ada hubungan antara riwayat keluarga hipertensi dengan kejadian hipertensi.

8) Hubungan antara obesitas dengan kejadian hipertensi

Tabel 8. Hubungan antara Obesitas dengan Kejadian Hipertensi di Puskesmas Umbulharjo I Yogyakarta Tahun 2009.

\begin{tabular}{ccccccccc}
\hline & \multicolumn{3}{c}{ Kejadian hipertensi } & & & \multicolumn{3}{c}{ Chi-square } \\
\cline { 2 - 4 } & Ya & Tidak & Total & $p$ & $\alpha$ & hitung & $d f$ \\
\hline Obesitas & 16 & 19 & 35 & & & & \\
\cline { 1 - 4 } Tidak obesitas & 10 & 43 & 53 & 0,007 & 0.05 & 7,298 & $1=3.481$ \\
\cline { 1 - 4 } Total & 26 & 62 & 88 & & & & \\
\hline
\end{tabular}

Tabel 8 diatas menunjukkan terdapat 16 responden yang obesitas mengalami hipertensi, responden yang tidak mengalami hipertensi tetapi obesitas berjumlah 19 orang. Responden yang mengalami hipertensi tetapi tidak obesitas berjumlah 10 orang, dan responden yang tidak mengalami hipertensi dan tidak 
obesitas berjumlah 43 orang. Berdasarkan hasil pengolahan data menunjukkan bahwa nilai $p=0.007<\alpha=0.05$, dan Chi Square hitung $7.298>$ Chi Square tabel 3,481 , berarti secara statistik ada hubungan antara obesitas dengan kejadian hipertensi.

9) Hubungan antara kontrasepsi hormonal dengan kejadian hipertensi

Tabel 9. Hubungan Penggunaan Kontrasepsi Hormonal dengan Kejadian Hipertensi di Puskesmas Umbulharjo I Yogyakarta Tahun 2009

\begin{tabular}{|c|c|c|c|c|c|c|c|}
\hline \multirow[t]{2}{*}{ Kontrasepsi hormonal } & \multicolumn{2}{|c|}{ Kejadian hipertensi } & \multirow[t]{2}{*}{ Total } & \multirow[t]{2}{*}{$p$} & \multirow[t]{2}{*}{$\alpha$} & \multirow{2}{*}{$\begin{array}{c}\text { Chi-square } \\
\text { hitung }\end{array}$} & \multirow[t]{2}{*}{$d f$} \\
\hline & Ya & Tidak & & & & & \\
\hline Menggunakan & 16 & 36 & 52 & & & & \\
\hline Tidak menggunakan & 10 & 26 & 36 & 0,762 & 0.05 & 0.091 & $1=3.481$ \\
\hline Total & 26 & 62 & 88 & & & & \\
\hline
\end{tabular}

Tabel 9 diatas dapat dilihat bahwa terdapat 16 responden yang menderita hipertensi dan menggunakan kontrasepsi hormonal, responden yang tidak hipertensi dan menggunakan kontrasepsi hormonal sebanyak 36 orang, responden yang hipertensi tetapi tidak menggunakan kontrasepsi hormonal, dan sebanyak 10 orang, responden yang tidak mengalami hipertensi dan tidak menggunakan kontrasepsi hormonal sebanyak 26 orang. Berdasarkan hasil pengolahan data menunjukkan bahwa nilai $p=0.608>\alpha=0.05$ dan Chi Square hitung $0.091<$ Chi Square tabel 3,481, berarti secara statistik tidak ada hubungan antara penggunaan kontrasepsi hormonal dengan kejadian hipertensi.

\section{b. Pembahasan}

1) Hubungan antara Riwayat Keluarga Hipertensi dengan Kejadian Hipertensi.

Hasil penelitian tentang hubungan antara riwayat keluarga hipertensi dengan kejadian hipertensi yaitu dari 88 responden, terdapat 20 responden yang mengalami hipertensi dan memiliki riwayat keluarga hipertensi. didapatkan nilai $p=$ 0.158 dengan $\alpha=0.05$, karena nilai $p$ lebih besar dari nilai $\alpha$, dan Chi Square hitung $1.992<$ Chi Square tabel 3,481, berarti secara statistik tidak ada hubungan antara riwayat keluarga menderita hipertensi dengan kejadian hipertensi pada wanita usia subur di Puskesmas Umbulharjo I Yogyakarta Tahun 2009.

Riwayat keluarga (orang tua, kakek/nenek, dan saudara kandung) yang menunjukkan adanya tekanan darah yang tinggi merupakan faktor risiko paling kuat bagi seseorang untuk mengidap hipertensi di masa yang akan datang. Berdasarkan penelitian yang telah dilakukan ini, menunjukkan bahwa riwayat keluarga tidak memilki hubungan dengan kejadian hipertensi pada wanita usia subur di Puskesmas Umbulharjo I Yogyakarta. Penyebab hipertensi karena faktor riwayat keluarga ini diketahui disebabkan oleh pola hidup yang kurang baik, dikaitkan dengan pola makan, jika seseorang menerapkan pola makan yang baik, kemungkinan orang tersebut akan terhindar dari hipertensi ${ }^{7}$. Seperti terlihat dari data distribusi responden berdasarkan status obesitas bahwa responden dalam penelitian ini kebanyakan tidak mengalami obesitas, hal ini berarti bahwa pola 
hidup responden sudah baik, sehingga responden tidak mengalami hipertensi meskipun mempunyai riwayat keluarga yang menderita hipertensi.

\section{2) Hubungan antara obesitas dengan kejadian hipertensi}

Hasil penelitian tentang hubungan antara obesitas dengan kejadian hipertensi didapat responden yang obesitas dan mengalami hipertensi sebanyak 16 orang. Nilai $p=0.007$ dengan $\alpha=0.05$ karena nilai $p$ lebih kecil dari nilai $\alpha$, dan Chi Square hitung $7.298>$ Chi Square tabel 3,481, berarti secara statistik ada hubungan antara obesitas dengan kejadian hipertensi pada wanita usia subur di Puskesmas Umbulharjo I Yogyakarta Tahun 2009. Orang yang memiliki berat badan berlebih cenderung memiliki tekanan darah yang lebih tinggi daripada orang yang memiliki berat badan normal atau kurus.

Obesitas sangat erat kaitannya dengan pola makan yang tidak seimbang. Di mana seseorang lebih banyak mengkonsumsi lemak dan protein tanpa memperhatikan serat. Kelebihan berat badan meningkatkan risiko terjadinya penyakit kardiovaskular karena beberapa sebab. Makin besar massa tubuh, makin banyak darah yang dibutuhkan untuk memasok oksigen dan makanan ke jaringan tubuh. Ini berarti volume darah yang beredar melalui pembuluh darah menjadi meningkat sehingga memberi tekanan lebih besar pada dinding arteri. Seseorang yang gemuk lebih mudah terkena hipertensi. Wanita yang sangat gemuk pada usia 30 tahun mempunyai risiko terserang hipertensi 7 kali lipat dibandingkan dengan wanita yang langsing dengan usia yang sama. ${ }^{8}$

\section{3) Hubungan antara penggunaan kontrasepsi hormonal dengan kejadian hipertensi}

Hasil penelitian tentang hubungan antara penggunaan kontrasepsi hormonal dengan kejadian hipertensi didapat responden yang menggunakan kontrasepsi hormonal dan mengalami hipertensi sebanyak 16 orang. Nilai $p=$ 0.762 , dengan $\alpha=0.05, p$ lebih besar dari nilai $\alpha$, dan Chi Square hitung $0,091<$ Chi Square tabel 3,481, berarti secara statistik tidak ada hubungan antara penggunaan kontrasepsi hormonal dengan kejadian hipertensi pada wanita usia subur di Puskesmas Umbulharjo I Yogyakarta Tahun 2009. Hal ini berarti bahwa penggunaan kontrasepsi hormonal tidak berpengaruh terhadap kejadian hipertensi.

Berdasarkan hasil penelitian yang dilakukan ini yang menyebutkan bahwa tidak ada hubungan antara penggunaan kontrasepsi hormonal dengan kejadian hipertensi dapat dikaitkan dengan faktor gaya hidup seperti kurang berolahraga dan pola makan yang salah, dimana biasanya pada pengguna kontrasepsi hormonal terjadi peningkatan berat badan, tetapi tidak semua penggunanya yang mengalami obesitas. Orang yang kurang berolahraga atau kurang beraktivitas dan tidak memperhatikan asupan makanan yang masuk ketubuh biasanya sulit untuk menurunkan berat badan, sehingga cenderung meningkatkan tekanan darah, jadi pengguna kontrasepsi hormonal tidak perlu merasa takut menderita hipertensi, selama pengguna kontrasepsi hormonal tersebut sering melakukan aktivitas fisik seperti olahraga dan selalu memperhatikan makanan yang masuk ke tubuhnya dengan mengurangi asupan kolesterol jahat dan mengkonsumsi makanan yang sehat, maka akan dapat terhindar dari penyakit hipertensi. 


\section{SIMPULAN DAN SARAN}

\section{a. Simpulan}

1) Tidak ada hubungan antara riwayat keluarga hipertensi dengan kejadian hipertensi pada wanita usia subur di Puskesmas Unbulharjo I, Yogyakarta Tahun 2009.

2) Ada hubungan yang bermakna antara faktor obesitas dengan kejadian hipertensi pada wanita usia subur di Puskesmas Umbulharjo I Yogyakarta Tahun 2009.

3) Tidak ada hubungan antara penggunaan kontrasepsi hormonal dengan kejadian hipertensi pada wanita usia subur di Puskesmas Umbulharjo I Yogyakarta Tahun

b. Saran 2009.

1) Bagi Puskesmas Umbulharjo I Yogyakarta

Sebagai salah satu Puskesmas Induk di Kecamatan Umbulharjo sebaiknya bisa memberikan informasi lebih tentang hipertensi kepada masyarakat, mulai dari pengertian, faktor risiko dan bahaya terjadinya komplikasi penyakit disebabkan oleh hipertensi. Bekerjasama dengan petugas - petugas lapangan yang mengkoordinasi disetiap wilayah kerja, pemberian informasi tersebut dapat diberikan melalui penyuluhan atau pembagian informasi dengan promosi kesehatan, media - media tertentu seperti leaflet, dan iklan - iklan layanan masyarakat di Televisi.

2) Bagi FKM UAD Yogyakarta Menggalakkan mahasiswa untuk bisa meneliti faktor - faktor risiko yang lain, yang diperkirakan berhubungan dengan kejadian hipertensi, misalnya faktor gaya hidup sebagai pemicu terjadinya tekanan darah tinggi, seperti kebiasaan mengkonsumsi alkohol dan kopi.

3) Bagi Masyarakat Umbulharjo I Yogyakarta

Masyarakat Umbulharjo Yogyakarta khususnya yang ada di wilayah kerja Puskesmas Umbulharjo I Yogyakarta, agar bisa lebih memperhatikan kesehatan mulai dari yang sekecil - kecilnya, dan melakukan tindakan pencegahan hipertensi, sehingga dapat menghindari terjadinya bahaya penyakit atau komplikasi di kemudian hari.

\section{DAFTAR PUSTAKA}

1. Susalit, E., IImu Penyakit Dalam, Balai Penerbit FK UI, Jakarta. 2001

2. Dhianingtyas, Y., Hendrati, L.Y., "Risiko Obesitas, Kebiasaan Merokok, dan Konsumsi Garam terhadap Kejadian Hipertensi pada Usia Produktif", The Indonesian Journal of Public Health, 1 (1) : 105-109. 2006

3. Wiryowidagdo, S., Sitanggang, M., Tanaman Obat untuk Penyakit Jantung, Darah Tinggi, dan Kolesterol, Agro Media Pustaka, Jakarta. 2002

4. Suryati, A., "Faktor - faktor yang berhubungan dengan terjadinya Hipertensi Essensial", Jurnal Kedokteran dan kesehatan, 2 (1) : 183-193. 2005

5. Supariasa, I.D.N., Bakri, B., Fajar, I., Penilaian Status Gizi, Penerbit Buku Kedokteran EGC, Jakarta. 2002

6. Puskesmas Umbulharjo I, Data Sistem Pencatatan dan Pelaporan Penyakit, Yogyakarta. 2008 
7. Hembing, D., Ramuan Tradisional untuk Pengobatan Darah Tinggi, Swadaya, Cetakan VIII, Jakarta. 2001

8. Purwati, S., Salimar, R., Perencanaan Menu untuk Penderita Tekanan Darah Tinggi, Penerbit Swadaya, Jakarta. 2005 